TITLE:

\title{
NOTES ON THE NAUPLIOSOMA AND NEWLY HATCHED PHYLLOSOMA OF IBACUS CILIATUS (VON SIEBOLD)
}

\author{
$\operatorname{AUTHOR}(\mathrm{S}):$
}

Harada, Eiji

\section{CITATION:}

Harada, Eiji. NOTES ON THE NAUPLIOSOMA AND NEWLY HATCHED PHYLLOSOMA OF IBACUS CILIATUS (VON SIEBOLD). PUBLICATIONS OF THE SETO MARINE BIOLOGICAL LABORATORY 1958, 7(1): 173-180

\section{ISSUE DATE:}

1958-12-20

URL:

http://hdl.handle.net/2433/174595

RIGHT: 


\title{
NOTES ON THE NAUPLIOSOMA AND NEWLY HATCHED PHYLLOSOMA OF IBACUS CILIATUS $(\text { VON SIEBOLD })^{1)}$
}

\author{
EIJI HARADA \\ Seto Marine Biological Laboratory, Sirahama
}

With Plates $I X-X I$ and 2 Text-figures

\section{Introduction}

The purpose of the present paper is to afford some contributions to the post-larval development of a common scyllarid lobster Ibacus ciliatus (vON SIEBoLD), together with some knowledge on the biology of its larvae.

For our knowledge of the phyllosoma larvae of Ibacus ciliatus, we have the reports of many investigators, such as DE HAAN (1833-1850), RICHTERS (1873), BALSS (1914), Stephensen (1923), Gurney (1936), Tokioka (1954), etc., but if these reports are consulted, it may clearly be shown that the phyllosomas which were treated and described in these reports are all of the later developmental stages, and no case in the earlier stages of the phyllosoma is available. This may be mainly due to that the phyllosomas in these reports are those largely obtained in the field by chance or during the courses of large-scaled oceanographical investigations. This may also be met with in the case if we take the phyllosomas of other species into account. For instance, if one intends to make comparison of the newly hatched phyllosomas of certain species, one will be sure to find a number of species of which the newly hatched phyllosoma is undescribed. Our present knowledge of the phyllosomas is so fragmental from the point of view of their life histories, that we are hardly able to trace a sequence of all stages of the phyllosomas of a definite species, and to compare them with any corresponding stages in other species. Much uncertainty is thus left to make it impossible to identify the phyllosomas of the field collection, even if these phyllosomas are possibly in the newly hatched stage.

Since the summer of 1956 , I have made some efforts to hatch out and breed up the phyllosomas of various Palinurids and Scyllarids in the laboratory, that are inhabiting in the vicinity of the Seto Marine Biological Laboratory. I have got some newly hatched phyllosomas of several species, but in no case I succeeded to metamor-

1) Contributions from the Seto Marine Biological Laboratory, No. 321.

Publ. Seto Mar. Biol. Lab., VII (1), 1958. (Article 7) 
phose them into their second stages. It is my intention to describe these newly hatched phyllosomas to enable to identify the phyllosomas of the field collections, contributing to obtain a better knowledge of their life histories, and here I deal with Ibacus ciliatus at the first step.

I would like to take this opportunity of extending my sincerest thanks to Dr. Huzio Utinomi, Dr. Denzaburo MiYAdi and Dr. Takasi Tokioka for many suggestions and valuable advice during the course of this study.

\section{Meterials and Methods}

Ibacus ciliatus commonly occurs on the sandy or muddy bottom, in somewhat deeper area along the coast of Kii Peninsula, and is captured by the trawl net.

On April 16th, 1958, I obtained two berried females from the commercial landings of the trawl-net fishery at Kii-Tonda, some seven kilometres south-east of the Laboratory, and kept them in an aquarium $\left(0.5 \times 0.5 \times 0.4 \mathrm{~m}^{3}\right)$. The eggs of one of these two females were in an advanced stage. The eggs were almost spherical and their diameters were ranging from $0.95 \mathrm{~mm}$ to $1.05 \mathrm{~mm}$. The embryos in advanced eggs had already absorbed most of their yolk and the eggs were whitish or almost transparent in appearance. Appendages of the embryos were well developed, closely folded around their bodies. The black pigmentation of their eyes was complete and very conspicuous. Their hearts were beating. The eggs of this female only could succeed to hatch out after four days rearing.

The hatching out occurred at the midday of April 20th. The female lifted her abdomen and shook it for several times, making the larvae escape from the eggs. She repeated this action for several times at the interval of about ten minutes, resulting the hatching out of the whole eggs. These larvae were not the phyllosomas but in the form of the naupliosoma as described by GILcririst (1913). They could swim about swiftly with the aid of their setose branched second antennae, some of them went upward to the surface and some of them stayed near the bottom. But this form was not held for a long time, and, within thirty minutes, these naupliosoma larvae moulted and took the form of the ordinary phyllosoma. The phyllosomas had no swimming second antennae, but they moved around with the aid of exopods of the thoracic appendages, as in cases of other species. It was a very remarkable fact that these newly hatched phyllosomas were never attracted to the light, but they went away from the light to the darker corner of the aquarium, showing negative phototaxis. These phyllosomas were kept and reared in the aquarium, from which the adult animals were removed after they hatched out, being feeded with the boiled egg-yellow. They ate it, but after five days rearing more than a half of them died, and all after fifteen days rearing, resulting no moult.

The naupliosoma and the newly hatched phyllosoma within several days after the hatching out are described below. 


\section{The First Stage Phyllosoma}

The newly hatched phyllosoma, just after the moult from the naupliosoma to this form, had somewhat shriveled body and was whitish in colour, but later became swelled and highly transparent. It measured at first $1.9-2.3 \mathrm{~mm}$ in the body length and $1.5-1.9 \mathrm{~mm}$ in the fore-body. width, but after a week $2.6-2.9 \mathrm{~mm}$ and $2.1-2.4 \mathrm{~mm}$ respectively.

The fore-body (cephalic shield) is almost quadrate in outline, but slightly concave at the posterior end, and broader than the hind-body, its width being about 1.5 times its length. The hind-body (thorax) is not concave behind. The abdomen is not

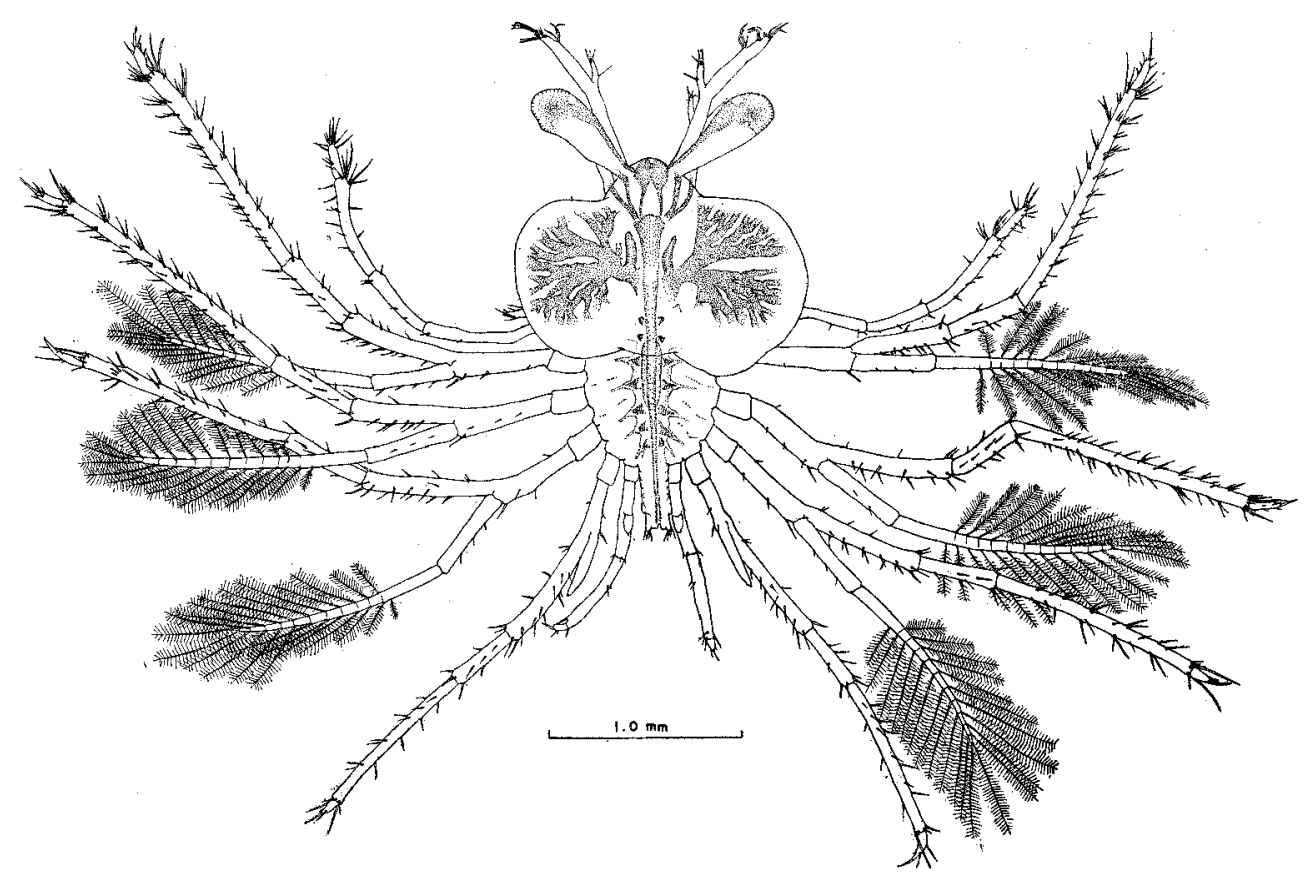

Fig. 1. The dorsal view of the newly hatched phyllosoma of lbacus ciliatus.

segmented and without trace of pleopods, ending in two pointed processes armed with three setae on each side.

The eyes are not stalked.

The first antenna (antennule) is long and has a short branch, not cut off at the base, on its inner-dorsal surface at the middle. The distal end of the first antenna bears a tuft of three long and a short setae. There are also other two tufts of long setae near the tip, composed of three and two setae respectively. The branch has two points at the tip and a very small seta near the base. The first antenna has no segmentation at all. 
The second antenna (antenna) is about half of the first antenna in length and also has a branch on the inner-dorsal side at the middle. The distal end of the second antenna is armed with two spinous processes. The branch, not cut off at the base, bears three setae at the tip and a very small seta near the tip. The second antenna is also unsegmented.

The mandible is very stout and ends in a complicatedly toothed blade edge.

The first maxilla has two branches, each of them being armed with spines and setae.

The second maxilla has two segments, the distal one being small and bearing four long setose setae.

The first maxilliped is a very small simple stump.

The second maxilliped is composed of five segments, without an exopod and not reaching the distal end of the second segment of the third maxilliped.

The third maxilliped is of five segments, without an exopod, and bears no stout claw-like spine at the distal end. Distal two segments are armed with setae.

The first, second and third legs, five-segmented, have well developed exopod on the dorsal side of the second segment of each. These legs are almost equal in length and 1.6-1.7 times as long as the body length. Last four segments have many setae. A large claw-like spine presents at the tip. The fourth segment is longer than others. The exopod is composed of two segments, about a half length of the leg, of which the distal one bears eleven to twelve pairs of long setose setae.

The fourth leg, with five segments and about $3 / 4$ length of the second leg, bears a rudimental, though somewhat elongated, exopod on the second segment, which is unsegmented and not definitely cut off at its base. Last four segments have setae, with a large spine at the end of the last segment.

The fifth leg, with four segments and a very rudimentary budlike exopod on the second segment not completely cut off, is about equal in length to the second maxilliped. Few setae present, but with a large spine at the tip.

The coxal spines are present on the legs from the first to the fourth, bearing an accessary seta on its base. On the maxillipeds, there is only a seta instead of the coxal spine.

The newly hatched phyllosoma of Ibacus ciliatus thus differs much from that of other species hitherto described. It is larger in size than that of Panulirus, Palinurus, Scyllarides, or Scyllarus, as described by NAKAzAwA (1917), JoHnson (1956), Cunningham (1892), Lebour (1950), etc. and also observed by myself. Moreover, we found distinct characteristics which have not been described yet in any reports, that is: (1) The first and second antennae are both biramous; (2) there exist five legs with an exopod; (3) numbers of the pair of the setose seta on the second segments of the exopods of the first to third legs are eleven to twelve, that are larger than that of Panulirus, Scyllarides and Scyllarus, but similar to that of Palinurus; (4) the fore-body is exceedingly broad; (5) legs are relatively shorter than in others. 


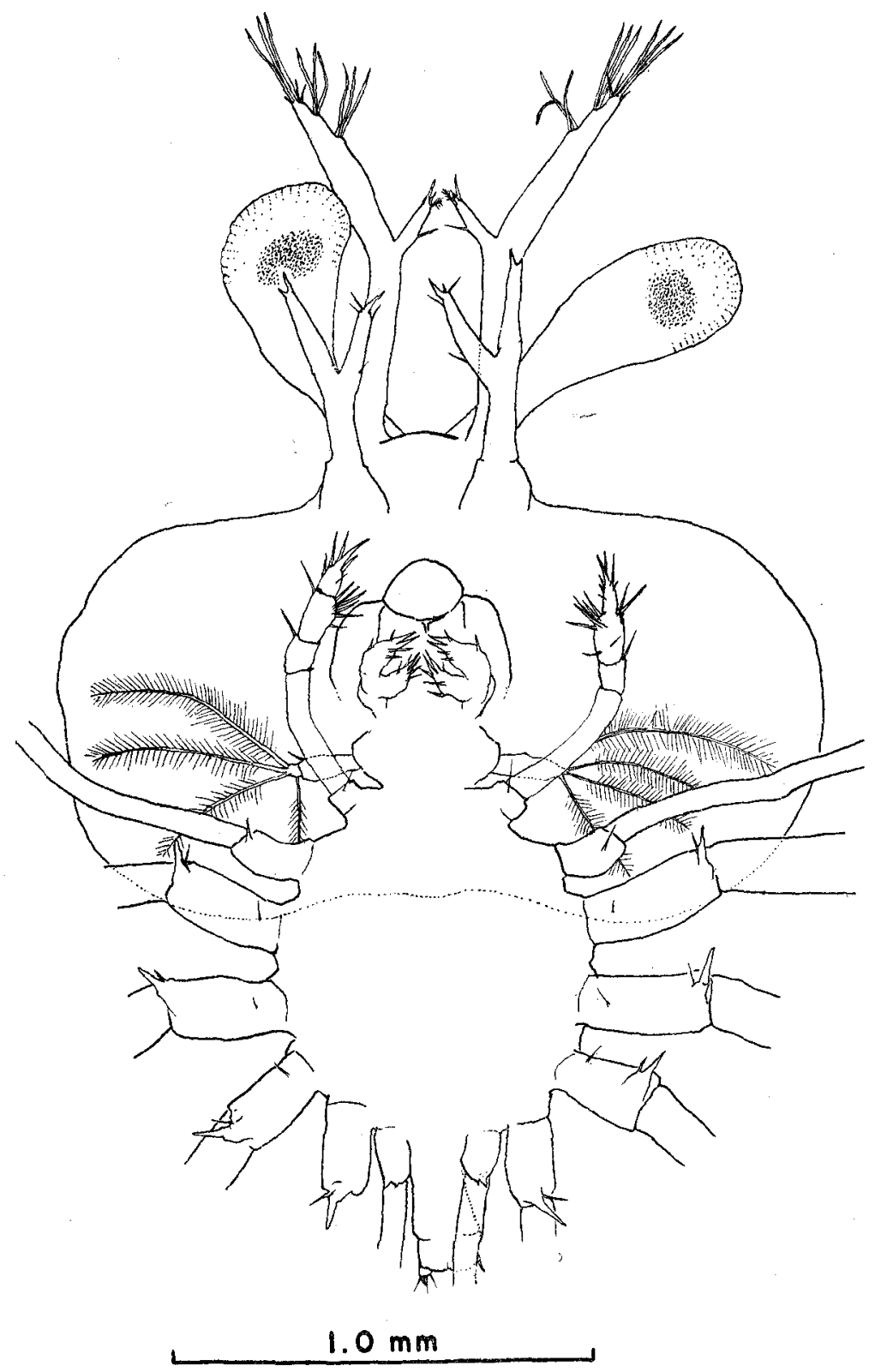

Fig. 2. The ventral view of the newly hatched phyllosoma of Ibacus ciliatus.

Although the definite conclusion must be awaited until other members of these genera of lobsters, including Ibacus itself, are examined more closely, these characteristics, especially the first two, might be considered as generic. 


\section{The Naupliosoma}

The naupliosoma of Ibacus ciliatus seems to be a free-swimming larva, but this stage is passed through in a very short time. As will be reported in the succeeding papers, the larvae of the form of the naupliosoma hatched out when the eggs in the advanced stage of Scyllarides squamosus (H. MILNE EDWARDS) were artificially shaken in the laboratory. Such naupliosoma-formed larvae of Scyllarides squamosus have setose, seven-branched, second antennae, but they are not able to swim at all. On the contrary, the naupliosoma of Ibacus ciliatus has strong power of swimming with the aid of second antennae.

The naupliosoma is enclosed in a thin membrane, through which the phyllosoma to be moulted is visible. So, there is no great difference in the basic plan of its structure between the naupliosoma and the newly hatched phyllosoma, except that there is no setae at all on appendages in the former and except for the form of the first and second antennae.

The first antenna of the naupliosoma is not biramous and has no setae as in the newly hatched phyllosoma described above, though the biramous first antenna of the following stage is discernible in it.

The second antenna terminates into eight setose branches, and is longer than that of the following stage, which is discernible in the first (proximal) and last (distalmost) branches.

\section{Field Collection}

The field collection has been made in shallow waters in front of the Seto Marine Biological Laboratory since the spring of 1955 , but no phyllosoma nor naupliosoma of the form described above was found in the towing samples, although many other phyllosomas were captured, mainly of Panulirus japonicus.

\section{Summary}

1. The naupliosoma and first stage phyllosoma of Ibacus ciliatus (VON SiEBOLD) were described, that were hatched out and reared in the laboratory.

2. It was suggested that the presence of the biramous first and second antennae and five legs from the first time when the larvae took the form of the phyllosoma might be took as the most conspicuous generic characters.

3. Some notes on the behaviour of the naupliosoma and newly hatched phyllosoma in an aquarium condition were presented.

\section{REFERENCES}

BALSS, H. 1914. Ostasiatische Decapoden. II. Die Natantia und Reptantia. Abh. Bayer. Akad. Wiss., II Kl. Suppl. Bd. 2, Abhlg. 10, no. 7, pp. 4-101, 1 PI. 
BAte, C. S. 1888. Crustacea Macrura. Development of the Scyllaridae. Challenger Rep., Zool., Vol. 24, pp. 95-100.

Cunningham, J. T. 1892. On the development of Palinurus vulgaris, the rock lobster or sea cray-fish. Journ. Mar. Biol. Assoc., n. s., Vol. 2, no. 2, pp. 141-150. 2 Pls.

Gilchrist, J. D. F. 1913. A free-swimming nauplioid stage in Palinurus. Journ. Linn. Soc. London, Zool., Vol. 32, no. 216, pp. 225-231.

GuRney, R. 1936. Larvae of decapod Crustacea. Part III. Phyllosoma. Discovery Rep., Vol. 12, pp. 400-440.

HAAN, W. DE, 1833-50. Crustacea. In : P. F. DE SIEbOLD's Fauna Japonica, pp. 1-244, Pls. 1$55, \mathrm{~A}-\mathrm{Q}$.

JoHnson, M. W. 1951. A giant phyllosoma larva of a loricate crustacean from the tropical Pacific. Trans. Amer. Microscop. Soc., Vol. 70, no. 3, pp. 274-278.

1956. The larval development of the California spiny lobster, Panulirus inter ruptus (RANDALI), with notes on Panulirus gracilis Streets. Proc. Calif. Acad. Sci., Ser. 4, Vol. 29, no. 1, pp. 1-19.

LEBour, M. V. 1950. Notes on some larval decapods (Crustacea) from Bermuda. I and II. Proc. Zool. Soc. London, Vol. 120, Part 2, pp. 369-379; Part 4, pp. 743-747.

LEwIS, J. B. 1951. The phyllosoma larvae of the spiny lobster Panulirus argus. Bull. Mar. Sci. Gulf and Caribbean, Vol. 1, pp. 89-103.

NAKAZAWA, K. 1917. Studies on the metamorphosis of Panulirus japonicus, with notes on the ecology of its larvae. Zool. Mag., Tokyo, Vol. 29, no. 347, pp. 259-267. (in Japanese.)

RICHTERS, F. 1873. Die Phyllosomen. Ein Beitrag zur Entwicklungsgeschichte der Loricaten. Zeitschr. f. Wiss. Zool., Band 23, no. 4, pp. 623-646, Pls. 31-34.

Stephensen, K. 1923. Decapoda Macrura. Rep. Danish Oceanogr. Expeds. 1908-10 to the Mediterranean and adjacent Seas, Vol. 2, no. 7, pp. 1, 4-85.

TokiokA, T. 1954. Droplets from the plankton net. XIV. Record of a scyllarid Phyllosoma near Seto. Publ. Seto Mar. Biol. Lab., Vol. 3, no. 3, pp. 361-368, Pls. 41-43. 


\section{EXPLANATION OF PLATES IX-XI}

\section{Plate IX}

The newly hatched phyllosoma of Ibacus ciliatus.

Fig. A. Left first and second antennae, dorsal view.

Fig. B. Mouth parts, ventral view.

Fig. C. Right second maxilla, ventral view.

Fig. D. Right second maxilla and first maxilliped, ventral view.

Fig. E. Blade edge of left mandible and left lower lip, ventral view.

Fig. F. Blade edge of right mandible, dorsal view.

Fig. G. Left first maxilla, ventral view.

Fig. H. Right second maxilliped, ventral view.

Fig. I. Right third maxilliped, ventral view.

Fig. J. Left fifth leg, dorsal view.

\section{Plate X}

The newly hatched phyllosoma of Ibacus ciliatus.

Fig. K. Second segment of exopod of left second leg, dorsal view.

Fig. L. Distal portion of left second leg. dorsal view.

Fig. M. Left fourth leg, dorsal view.

Fig. N. Coxal spines of left second to fourth leg, ventral view.

Fig. O. Abdomen, dorsal view.

\section{Plate XI}

The naupliosoma of Ibacus ciliatus.

Fig. P. Right first antenna, dorsal view.

Fig. Q. Left second antenna, dorsal view.

Fig. R. Right second maxilla and second maxilliped, ventral view.

Fig. S. Left third maxilliped and first leg, dorsal view.

Fig. T. Abdomen and right fourth and fifth legs, dorsal view. 
Publ. Seto Mar. Biol. Lab., VII, 1 (1958)
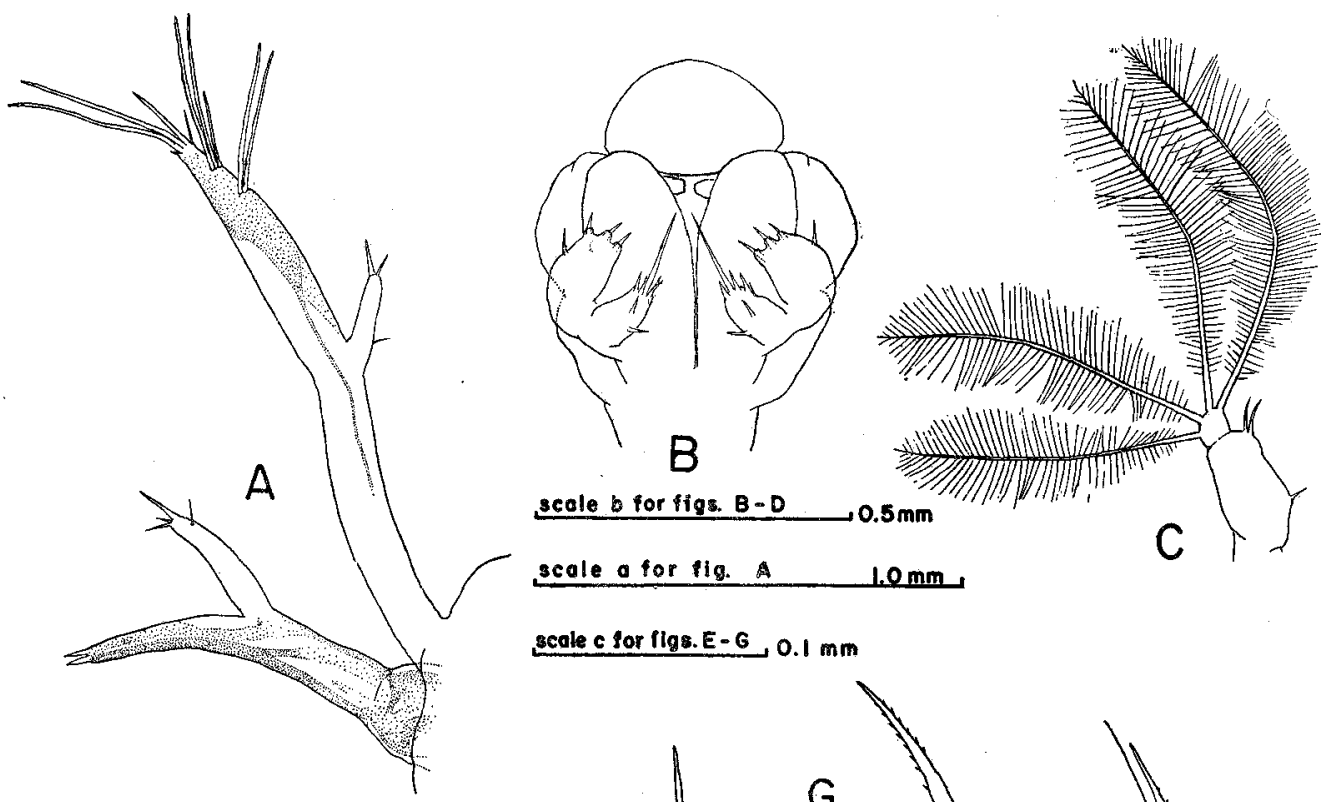

scale ofor tig. $1.0 \mathrm{~mm}$

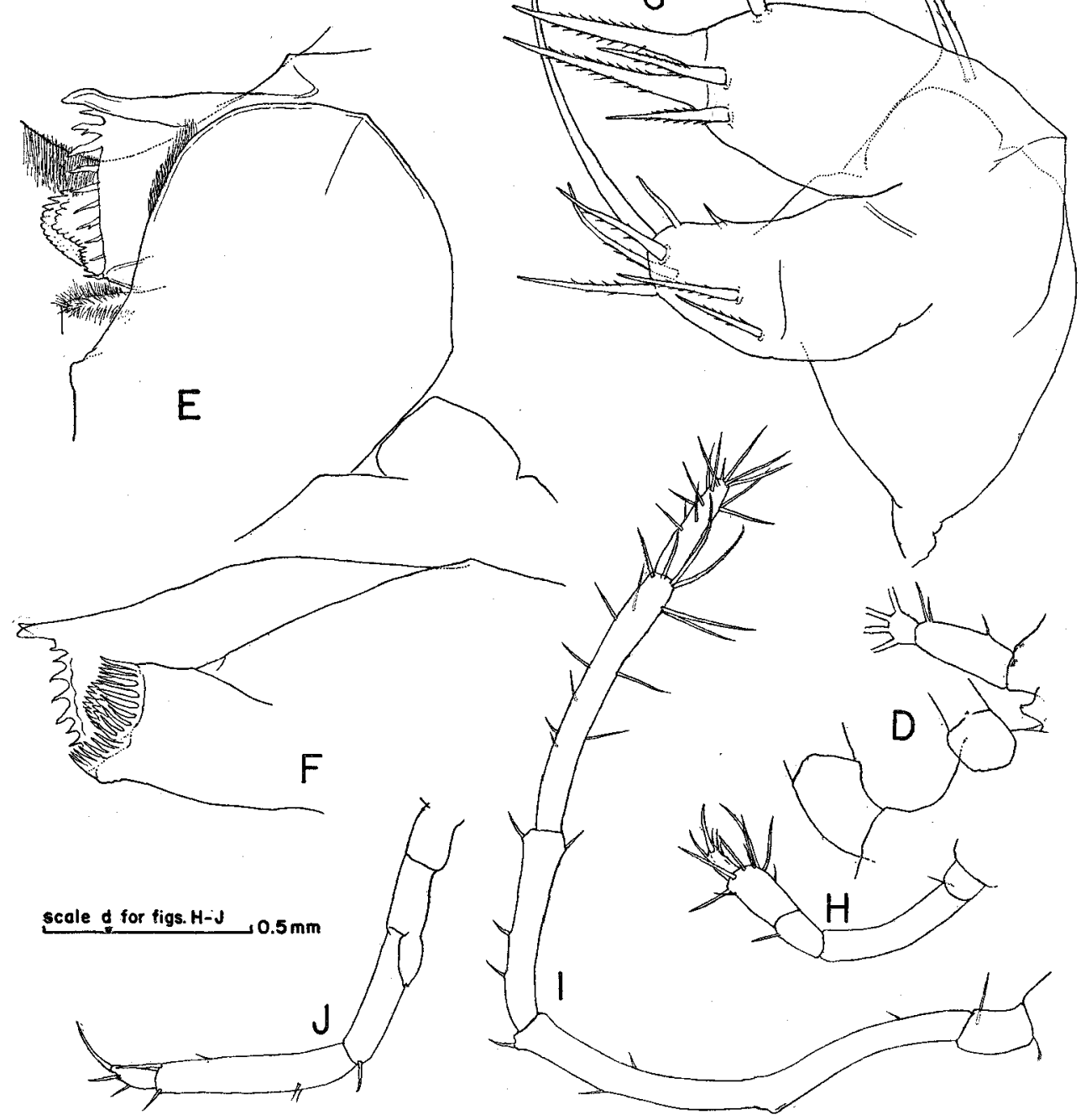

E. Harada: Naupliosoma and Phyllosoma of Ibacus ciliatus. 
Publ. Seto Mar. Biol. Lab., VII, 1 (1958)

PLATE X

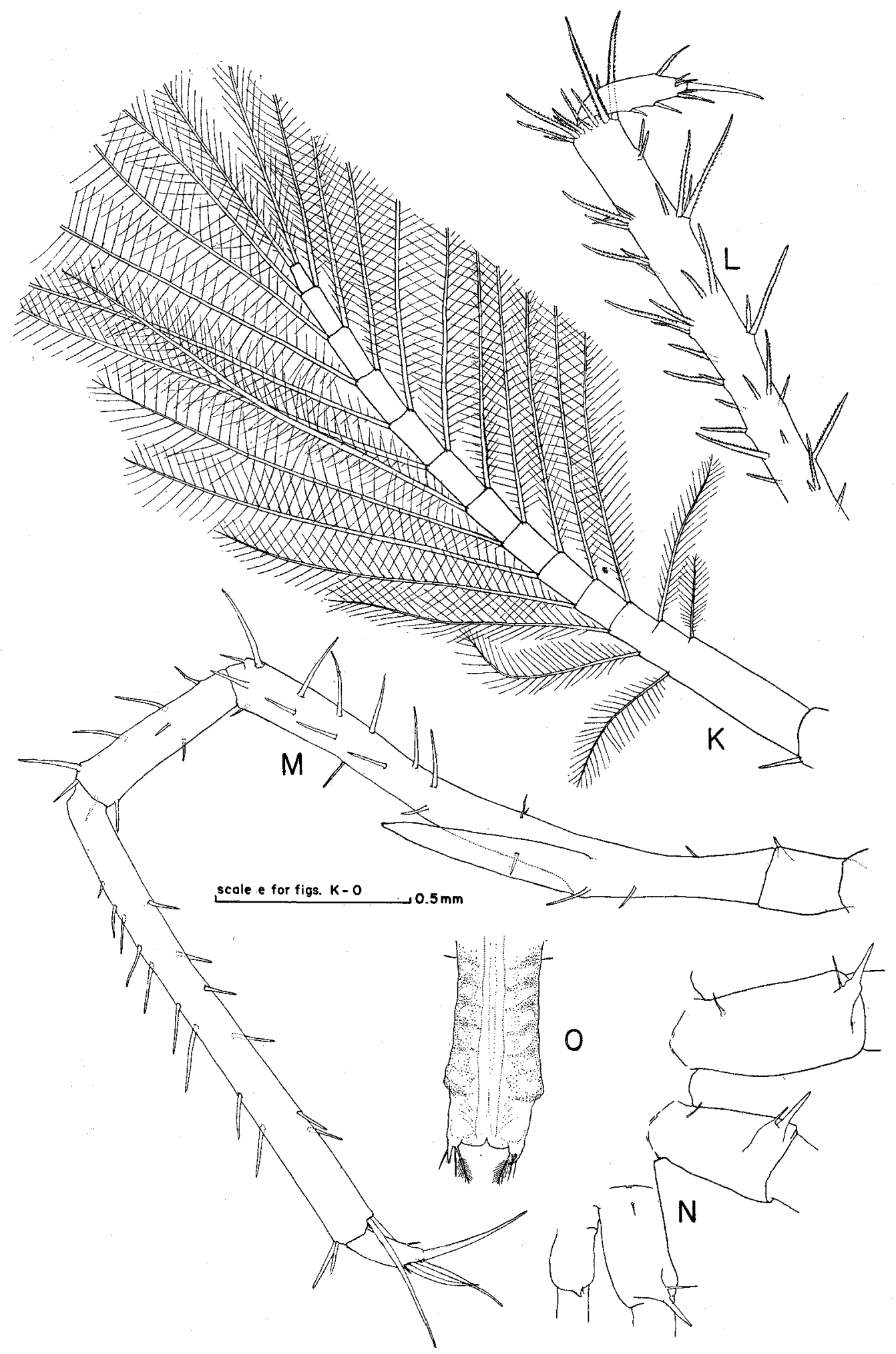

E. Harada: Naupliosoma and Phyllosoma of Ibacus ciliatus. 
Publ. Seto Mar. Biol. Lab., VII, 1 (1958)
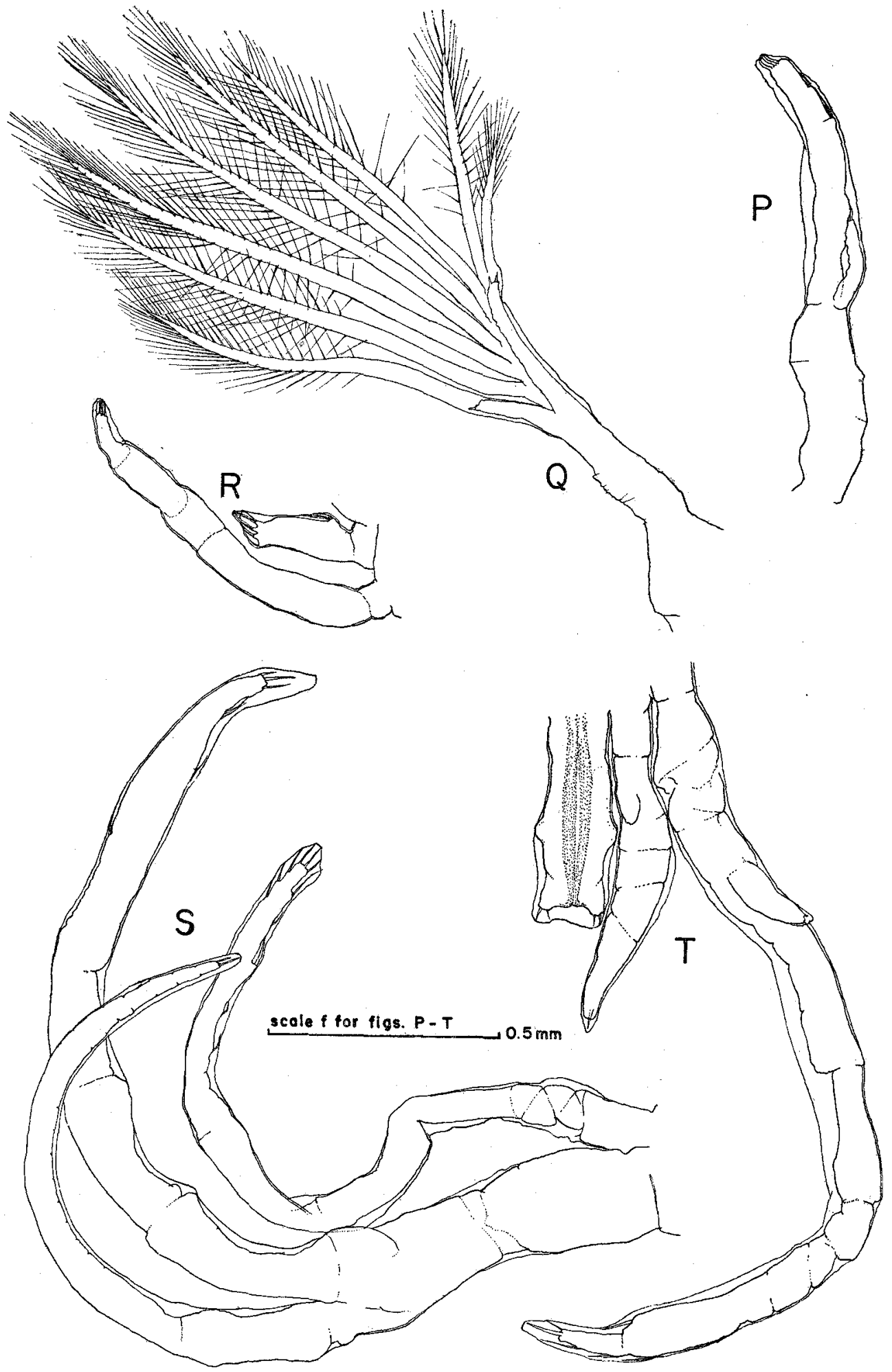

E. Harada: Naupliosoma and Phyllosoma of Ibacus ciliatus. 